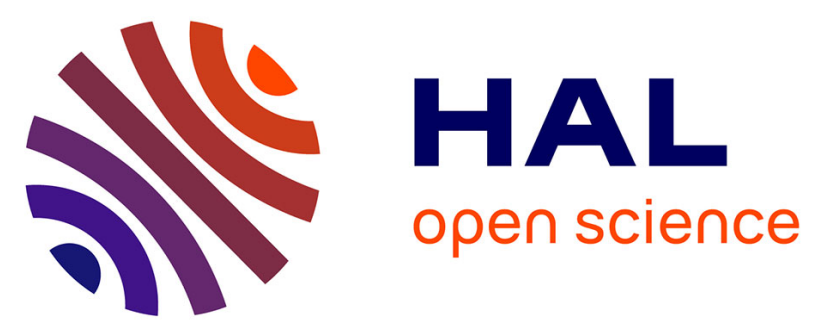

\title{
Human herpesvirus 6 infection after autologous stem cell transplantation: A multicenter prospective study in adult patients
}

Marie Balsat, Sylvie Pillet, Emmanuelle Tavernier, Victoria Cacheux, Vanessa

Escuret, Cécile Moluçon-Chabrot, Karine Augeul-Meunier, Audrey Mirand, Christel Regagnon, Fabien Tinquaut, et al.

\section{To cite this version:}

Marie Balsat, Sylvie Pillet, Emmanuelle Tavernier, Victoria Cacheux, Vanessa Escuret, et al.. Human herpesvirus 6 infection after autologous stem cell transplantation: A multicenter prospective study in adult patients. Journal of Infection, 2019, 79 (1), pp.36-42. 10.1016/j.jinf.2019.05.001 . hal-02299171

\section{HAL Id: hal-02299171 \\ https://hal.science/hal-02299171}

Submitted on 25 Oct 2021

HAL is a multi-disciplinary open access archive for the deposit and dissemination of scientific research documents, whether they are published or not. The documents may come from teaching and research institutions in France or abroad, or from public or private research centers.
L'archive ouverte pluridisciplinaire HAL, est destinée au dépôt et à la diffusion de documents scientifiques de niveau recherche, publiés ou non, émanant des établissements d'enseignement et de recherche français ou étrangers, des laboratoires publics ou privés.

\section{(ㅇ)(1) $\$$}

Distributed under a Creative Commons Attribution - NonCommerciall 4.0 International 
1 Human Herpesvirus 6 Infection after Autologous Stem Cell Transplantation: A

2 Multicenter Prospective Study in Adult Patients.

3

Marie Balsat ${ }^{1,2}$, Sylvie Pillet ${ }^{3}$, Emmanuelle Tavernier ${ }^{1}$, Victoria Cacheux ${ }^{4}$, Vanessa Escuret $^{5}$, Cécile Moluçon-Chabrot ${ }^{4}$, Karine Augeul-Meunier ${ }^{1}$, Audrey Mirand ${ }^{6}$, Christel Regagnon6, Fabien Tinquaut7, Véronique Bousser ${ }^{7}$, Mathieu Oriol ${ }^{7}$, Denis Guyotat ${ }^{1}$, Gilles Salles², Jacques-Olivier Bay5, Bruno Pozzetto³ , and Jérôme Cornillon¹.

${ }^{1}$ Institut de Cancérologie Lucien Neuwirth, Hematology Department, Saint-Priest-enJarez, France

${ }^{2}$ Hospices Civils de Lyon, Centre Hospitalier Lyon Sud, Hematology department, Pierre Bénite, France

${ }^{3} \mathrm{CHU}$ de Saint-Etienne, Laboratory of Infectious Agents and Hygiene, Saint-Etienne, France

${ }^{4}$ CHU Clermont-Ferrand, Hematology Department, Clermont-Ferrand, France ${ }^{5}$ Hospices Civils de Lyon, GHN, Laboratoire de Virologie, F-69317, Lyon, France ${ }^{6} \mathrm{CHU}$ Clermont-Ferrand, Laboratory of Virology, F-63003 Clermont-Ferrand, France 7Institut de Cancérologie Lucien Neuwirth, Centre Hygée, Saint-Priest-en-Jarez, France

\section{Corresponding author:}

Dr Marie Balsat, MD

Hematology department

Pavillon Marcel Bérard

Centre Hospitalier Lyon Sud

165 chemin du Grand Revoyet

69495 Pierre Bénite

France

Tel : +33(0)4 78862250

Fax : +33(0)4 72678880

e-mail: marie.balsat@chu-lyon.fr

Keywords: HHV-6, autologous stem cell transplantation, early infection, thrombocytopenia, neutropenia

Running title: HHV-6 after Autologous Stem Cell Transplantation 


\section{ABSTRACT}

Objectives: to prospectively evaluate the incidence and the clinical relevance on hematopoietic reconstitution of HHV-6 infection in autologous hematopoietic stem cell transplantation (ASCT) recipients.

Methods: HHV-6 DNA load was measured in whole blood specimens once during the 7 days before stem cell re-infusion and once a week after transplantation until hematopoietic recovery. Active HHV-6 infection was defined by 2 consecutive positive DNA loads.

Results: from July 2012 to February 2015, 196 adult patients undergoing ASCT were enrolled. Twenty-two (11.2\%) patients developed active HHV-6 infection with a cumulative incidence of $19 \%$ at 40 days after transplantation. The onset of active HHV-6 infection occurred with a median of 13 days after stem cell re-infusion. HHV-6 infection was associated with an increased frequency of non-infectious complications $(\mathrm{OR}=5.05$; 95\%CI 1.78-14.32; $P<.001)$. Moreover, the severity of these non-infectious complications was higher in recipients exhibiting HHV-6 infection $(\mathrm{OR}=4.62 ; 95 \% \mathrm{CI}$ 1.32-16.2; $\mathrm{p}<.01$ ). Delayed neutrophils 10 (IQR: 8-14) vs 8 (IQR: 6-11) days and platelets recoveries 15 (IQR: 11.8-18.5) vs 8 (IQR: 4-14) days were observed in patients with active HHV-6 infection compared to non-infected ones.

Conclusions: in this study, $11.2 \%$ ASCT recipients presented active HHV-6 infection associated with significantly delayed hematologic reconstitution.

Words: 199

\section{Highlights:}

-Active HHV-6 infection occurred in $11.2 \%$ of autologous stem cell recipients -HHV-6 infection is associated to increased frequency of non-infectious complications 
65 -Non-infectious complications are more severe when associated to HHV-6 infection

66 - HHV-6 infection is associated with delayed neutrophils and platelets recoveries 
Human herpesvirus type 6 (HHV-6) is a widespread roseolovirus which encompasses two different variants: HHV-6A and HHV-6B sharing 75\%-95\% nucleotide sequence identity. Variant B is the most commonly detected in clinical specimens: it is considered as the causative agent of the exanthema subitum childhood disease with an estimated seroprevalence of $>95 \%$ after the age of 2 years and of pathologies described in immunocompromised patients(1-3). To date, variant A seems less frequently detected (4). Like other herpesviruses, HHV-6 establishes a life-long latency; involved organs are brain, bone marrow and salivary glands, with a strong tropism for T-lymphocytes, hematopoietic CD34+ progenitor cells and microglia(2, 5). HHV-6 is also unique among human viruses because of the ability of both variants for chromosomal integration (ciHHV-6)(6).

If only few cases of HHV-6 symptomatic reactivation have been reported in immunocompetent patients(7), HHV-6 reactivation rather occurs in immunocompromised hosts such as allogeneic hematopoietic stem cell transplantation (allo-SCT) recipients(8, 9), solid organ transplanted patients(10) and HIV-infected patients(11), causing diverse benign to severe clinical manifestations including fever(12), thrombocytopenia, encephalitis(13), pneumonitis and hepatitis(14). In the allo-SCT setting, HHV-6 opportunistic infection is associated with poor outcome,

86 including acute graft-versus-host disease (GVHD)(15, 16), susceptibility to cytomegalovirus (CMV) disease(17), and delayed platelet recovery (18) resulting in an increased transplant related mortality(19).

89 Autologous hematopoietic stem cell transplantation (ASCT) is widely used for the treatment of myeloma and lymphoma(20) as well as some solid tumours(21). ASCT

91 patients are generally thought to have less viral infections than allo-SCT patients and, 
apart systematic CMV viraemia measurement, other herpesviruses are not regularly monitored in ASCT patients. Nevertheless, some ASCT recipients may develop delayed haematological recovery(8, 22) but also fever(23), febrile neutropenia, thrombocytopenia, microangiopathy, diarrhoea, interstitial pneumonitis, encephalitis and cutaneous rashes(24), all of them being compatible with HHV-6 infection(25). To date, the number of studies exploring viral infections in ASCT population is limited with only small series, evaluating the impact of HHV-6 infection in paediatric ASCT(26, 27), mixing the analysis of allo-SCT and ASCT(9), or using mostly qualitative assays without measurement of the viral load; no recent data with clear recommendations for the

101 follow-up of HHV-6 infection in adult ASCT is published.

102 The primary objective of this prospective multicentre non-randomized study was to 103 evaluate the incidence of HHV-6 infections in adult ASCT recipients using a strict 104 definition of active HHV-6 infection by 2 consecutive DNA loads measured by 105 quantitative real-time PCR (qPCR) in whole blood specimens. Secondary endpoints 106 included the clinical consequences of this infection on hematopoietic reconstitution, CMV co-infection and other infectious and non-infectious complication. 


\section{Patients and Study Design}

111 Adult patients, undergoing ASCT regardless of haematological malignancies at Saint-

112 Etienne, Lyon and Clermont-Ferrand University Hospitals in France, were prospectively 113 enrolled in this longitudinal multicentre non-randomized VIRAUTO6 study 114 (ClinicalTrials.gov NCT02090803) between July 2012 and February 2015. Patients 115 already included in the present study and receiving a second auto graft were excluded. 116 Written informed consent was obtained from all patients in accordance with the 117 Declaration of Helsinki. The study was approved by the local Ethics Committee of Saint118 Etienne and was established for the unique purpose of studying HHV6.

119 The follow-up period started at stem cell re-infusion day and ended at hospital 120 discharge if hematopoietic recovery was reached without transfusion support, and with 121 a maximum of 40 days after transplantation. Chemotherapy-related toxicities were 122 assessed according to the common terminology criteria for adverse events (CTCAE) 123 classification(28).

\section{HHV-6 and CMV DNA Monitoring}

126 Whole blood quantitative HHV-6 DNA was measured once during the 7 days before stem 127 cell re-infusion and once per week after transplantation, until hematopoietic 128 reconstitution. The test was centralized in the Laboratory of infectious Agents and 129 Hygiene of Saint-Etienne University Hospital. After sampling, whole blood was 130 immediately frozen at $-20^{\circ} \mathrm{C}$ and sent on the same day to the laboratory. HHV-6 DNA 131 load was measured by qPCR in whole blood specimens as previously described(29). The 132 limit of quantification was estimated to 450 copies/mL. HHV-6 DNA from both variants 
133 (HHV6-A and HHV6-B) was amplified by the assay with consensus primers without 134 differentiation.

135 Because HHV-6 is frequently associated with CMV infection(12, 22), CMV monitoring 136 was performed in parallel; CMV DNA loads were quantified in the virology laboratory of each participating centre by using their own qPCR-based CMV commercial kit on whole blood specimens sampled the same day as that for HHV-6 DNA load determination.

\section{Definitions}

141 In order to exclude very low and transient HHV-6 DNA loads, active HHV-6 infection was 142 defined as 2 consecutive blood HHV-6 DNAemias $\geq 450$ copies $/ \mathrm{mL}$, one week apart. In 143 case of viral load>100,000 copies/mL on 2 samples, ci-HHV6 was suspected and a piece 144 of dander (finger nail or hair follicle) was analysed for HHV-6 DNA load; ci-HHV-6 was assessed if HHV-6 DNA was detected in dander (finger nail or hair follicle).

146 BEAM conditioning regimen includes Carmustine, Etoposide, Cytarabine and Melphalan 147 chemotherapies.

148 Neutropenia recovery was defined as absolute neutrophil count (ANC) $>0.5 \times 10^{9} / \mathrm{L}$ for 149 two consecutive days. Platelets recovery was defined as platelets count $>20 \times 10^{9} / \mathrm{L}$ 150 without transfusion support. The neutropenia and thrombocytopenia periods were 151 defined as the time from stem cell re-infusion to neutrophils and platelets recoveries 152 without transfusion support, respectively.

153 HHV-6 clinical disease in our cohort was defined according to the combination of the 154 following criteria as previously reported(12): the convergence between the chronology 155 of clinical events and the dynamics of HHV-6 DNAemia, the correspondence between the 156 nature of symptoms and the bodily site of HHV-6 infection and the absence of any other 157 pathogen known as cause of the disease. 
159 Before starting the study, a sample size of 196 inclusions was planned to give a HHV-6 160 reactivation cumulative incidence of $48 \%(30)$ with a confidence interval of $95 \%$ and an 161 accuracy of $7 \%$. All quantitative data were expressed as median with interquartile range 162 (IQR). All categorical data were expressed as frequencies (percent). Quantitative data 163 were compared between groups using the Kruskall-Wallis test; categorical data were 164 compared using the $\chi^{2}$-test (or the Fisher exact test). The incidence analyses and related 165 figures were performed using the Kaplan-Meyer method (Log-rank test). To analyse the 166 association between HHV6 reactivation and neutrophils/platelets recoveries, a 167 landmark analysis was performed including as landmark time the median of 168 reactivation (13 days). Cox models were used for multivariate survival analyses. Only 169 variables with p-value $<0.2$ in univariate analysis were introduced in the multivariate 170 models.

171 Statistical analyses were carried out using R software version 3.2.5. All $P$ values were 172 two-sided, with $P<.05$ denoting statistical significance. 


\section{RESULTS}

\section{Patients' characteristics}

176 Between July 2012 and February 2015, 196 adult patients underwent peripheral blood ASCT and were included in our study. The patient characteristics are summarised in Table 1. The median follow-up was 16 (IQR: 14-20) days. No patients died over the

179 whole follow-up period.

\section{Incidence of active HHV-6 infection and HHV-6 clinical disease}

Twenty-two patients (11.2\%) developed an active HHV-6 infection as defined above, with a cumulative incidence of $19 \%$ at 40 days after transplantation (Figure 1). Fiftyeight patients exhibited a positive ( $\geq 450$ copies/mL) HHV-6 DNA load on a single whole blood specimen with $30 \%$ of incidence. However, these additional cases were not considered as active HHV-6 infections according to our definition and they were 187 included into the control group (i.e non-infected patients). HHV6 was not detected before ASCT except for 3 patients who exhibited a very low HHV-6 DNAemia (just equal to 450 copies $/ \mathrm{mL}$ ) before stem cell re-infusion; all these 3 patients developed HHV-6

190 infection after ASCT. Among the 196 patients, none was suspected for ci-HHV-6 and no 191 case was described.

192 Active HHV-6 infection occurred with a median of 13 days (IQR: 12-15.8) after 193 transplantation and a median blood HHV-6 DNAemia of 7035 copies/mL (IQR: 1192.8 194 19875.7). Among the patient's characteristics (Table 1), only the underlying diseases 195 and the conditioning regimen differed significantly between the 2 groups with more 196 BEAM regimen and lymphoma in the group with active HHV-6 infected patients. In 197 univariate analysis, neither sex, age, disease status at time of stem cell re-infusion, 
number of courses of chemotherapy preceding ASCT nor the conditioning regimen did favour HHV-6 infection (Table 2). Nevertheless, multivariate survival analysis could not

200 be performed since no variable had a p-value $<0.2$ in univariate analysis.

201 For 3 patients, symptoms were compatible with HHV-6 clinical disease $(1.5 \%$ of the

202 cohort): 2 patients had skin rash with positive skin biopsy for HHV-6 DNA and 1 patient 203 had fever with no other cause than HHV-6 infection. For 2 patients, ganciclovir 204 treatment was introduced successfully for a median duration of 12 (Range: 8-15) days.

205

\section{Active HHV-6 infection and CMV co-infection}

207 Only one active CMV infection with at least 2 positives consecutive CMV DNA loads 208 during the same period was observed in a 69-year-old man undergoing BEAM-ASCT for 209 a mantle-cell lymphoma. At transplant time, his haematological disease was in partial 210 response. He suffered from grade 3 mucositis. Neutropenia recovery took 12 days while

211 platelets recovery took 30 days. The HHV-6 DNA load was positive 22 days after ASCT, 212 with a value of 10,900 copies/mL and a persistent HHV-6 DNA load was observed the 18 213 following days, at a lower value however (between 636 and 1,450 copies/mL). At day 27 214 post-ASCT, a positive CMV DNA load was detected (1,050 copies/mL, i.e. $231 \mathrm{UI} / \mathrm{mL})$ 215 and persisted until the end of the 40 days follow-up for this patient. This patient did not 216 receive any antiviral treatment.

\section{Active HHV-6 infection and hematopoietic reconstitution}

219 During the study period, all patients recovered from neutropenia, and 173 patients $220(88.3 \%)$ recovered from thrombocytopenia. The median neutropenia and 221 thrombocytopenia durations were 8 (IQR: 7-11) days and 8 (IQR: 4-16) days, 222 respectively. Delayed ANC and platelets recoveries were observed in patients with 
223 active HHV-6 infection compared to those without HHV-6 infection. The median

224 duration of ANC recovery was increased to 10 (IQR: 8 - 14) vs 8 (IQR: 6-11) days.

225 Recipients exhibiting active HHV-6 infection had platelets recovery duration longer

226 whatever the threshold used: platelets recovery $>20 \times 10^{9} / \mathrm{L}, 15$ vs 8 days and platelets

227 recovery $>50 \times 10^{9} / \mathrm{L}, 25$ vs 15 days. (cf. Figures $2 \mathrm{~A}$ and $2 \mathrm{~B}$ ).

228 Therefore, the duration of hospitalisation was significantly longer for patients with 229 active HHV-6 infection with a median duration of 30.5 days (IQR: $26.2-34$ ) vs 22 days 230 (IQR: 19 - 25) for patients without infection $(P<0.001)$. Similarly, HHV-6-infected 231 patients required transfusions later than non-infected patients: the median time 232 between transplant and last transfusion was longer for HHV-6-infected patients with 17 233 days (IQR: 15 - 22) compared to those without infection with 12.5 days (IQR: $10-18 ; P=$ $234.006)$.

235

\section{Active HHV-6 infection and other complications}

237 Febrile neutropenia occurred in 124 patients (63.3\%); the main site of infection was peripheral blood (septicaemia, 31.1\%) and the main pathogens identified were Gram negative bacilli (24.3\%), (Table 3). For one third of patients (33.4\%), febrile neutropenia

240 was not documented.

241 Non-infectious complications occurred in 195 patients $(99.5 \%)$ with a median of 4 242 complications (IQR: 3-5) per patient. These complications were grade 1 and 2 in $68.4 \%$ 243 of cases, grade 3 in $23.3 \%$ of cases and grade 4 in $3.4 \%$ of cases. The most frequent non244 infectious complication was oral mucositis that occurred in 158 patients (80.6\%) with a 245 maximum grade 3 in $40.5 \%$ of cases. The mucositis median duration was 8 days (IQR: 5246 11). The other frequent non-infectious complications were diarrhoea (69.4\%), liver 247 enzyme elevation (64.8\%), skin rash (35.2\%) and acute kidney injury (13.8\%). 
248 Although diarrhoea and mucositis were more frequent in non HHV-6 infected patients 249 than in infected ones (Table 3), active HHV-6 infection was associated with an increased 250 number of combined non-infectious complications (OR 5.05; 95\%CI 1.78-14.32; $P<.001$ ). 251 Moreover, the severity of these complications was higher in this group with more grade 252 3-4 complications (0R 4.62; 95\%CI 1.32-16.2; $P=.006)$. 
To date, this study is the first large-scaled multicentre prospective non-randomized study including 196 autologous stem cell transplants recipients. The first aim was to determine the incidence of active HHV-6 infection: it was of $11.2 \%$ with a cumulative incidence of $19 \%$ at 40 days after transplantation. Few studies had already addressed this question in the setting of ASCT: the retrospective works of Imbert-Macille et al., 260 Inazawa et al. and more recently Colombier et al. reported an incidence of HHV-6 261 infection of $42.5 \%, 11.4 \%$, and 8;5\%, respectively $(9,23,31)$. All defined the presence of any level of HHV-6 DNA in blood as active HHV-6 infection. In our work, in order to overcome blips of DNAemia, 2 consecutive blood HHV-6 DNAemias were needed to assess the diagnosis of active HHV-6 infection and to appreciate its kinetics. Up to date, no threshold has been formally recognised as the frontier between latent infection and active infection: in order not to omit low reactivations, we opted for a reference value of blood HHV-6 DNAemias $\geq 450$ copies/mL. By using the same criteria as in the studies listed just above, the HHV-6 incidence raised to almost $30 \%$ in our study. In accordance with Imbert-Marcille et al. who assessed that active HHV-6 infection frequently occurred early after transplantation with a median of 16 days in the ASCT cohort(9), HHV-6

271 infection occurred with a median time of 13 days in our cohort. HHV-6 and CMV DNAemias are either monitored on whole blood or plasma specimen, depending on the choice of the laboratory. In Europe, and especially in

274 France $(4,22,23,29,32,33)$, whole blood is the first used, mainly because this specimen 275 has very limited preparation phases at the preanalytical step (no isolation of leucocytes and no centrifugation of plasma that could lyse cells(1)). This specimen can also be used in case of agranulocytosis, allows the detection of virus replication earlier, and allows 
the detection of the ci-HHV-6 when present $(4,6)$. Most studies cited above monitored HHV-6 in whole blood specimen $(23,31,34)$. Although detection of viral mRNA could be useful to analyse latent (35), this tool is not currently used in routine and consequently we could not conclude on the presence of latent infection in our patients. Moreover, given the HHV-6 DNA loads were all $<100,000$ copies $/ \mathrm{mL}$ and not persistent, we could exclude ci-HHV-6. As the patients were all adults, the probability they had already met the virus was high. Consequently, we considered that active HHV-6 infections were reactivations.

The main limitation of our study is that the median follow-up of patients was shorter (16 days) than expected initially (ideally 40 days), which could have led to miss a few delayed infections and participate to minimize HHV-6 incidence. This short followup does not result neither from an early and voluntary study exit decided by clinicians nor a lost to follow-up, but it is rather explained by hospital discharge at the time of neutropenia recovery whatever platelet recovery or transfusion support need. In patients with haematological malignancies and after stem cell transplantation, Ljungman et al. defined HHV-6 infection as HHV-6 detected in a previously HHV-6seropositive patient(36). In our cohort, clinical relevance of HHV-6 infection was low, as it has been already reported in ASCT patients(31). However, HHV-6 disease could be highly suspected for 3 patients, with detection of HHV-6 DNA in skin biopsy for 2 of them. This was also reported in the literature(34). HHV-6 infection occurred more frequently in patients with BEAM conditioning 299 regimen. However, BEAM is more used for lymphoma in which immunity was probably 300 lower than plasmocytoma disorder in part because of immunotherapy as rituximab used 301 before. Moreover, due to supply difficulties of Carmustine, some patients $(n=16)$ 302 received Bendamustine, an immunosuppressive agent combining alkylating and 
antimetabolite properties known to cause T-cell lymphopenia(37). By now, it is too early

to assess whether this regimen (Bendamustime-EAM) promoted viral infections but vigilance regarding this question is required in the future.

We also hypothesized that HHV-6 infections may correlate with other opportunistic challenging viruses such as CMV. Both CMV and HHV-6 are lymphotropic viruses and are reported to be simultaneously or successively detected in allo-SCT recipients $(12,22)$. In our cohort, only one patient had concomitant CMV and HHV-6

310 infections. This low association is concordant with previous studies: Jeulin et al. showed 311 that HHV-6 DNAemia was not significantly associated with CMV infection in a cohort of 312220 allo-SCT patients including 44 HHV-6 infections(32); Horowitz et al. also showed 313 only one patient with concurrent reactivation of CMV out of the 10 ASCT patients 314 diagnosed with HHV-6 reactivation(38).

The second objective of our study was to analyse hematopoietic reconstitution in ASCT patients. CD34+ hematopoietic progenitors can indeed carry latent HHV-6 and

317 hematopoietic differentiation can lead to HHV-6 reactivation giving an explanation for myelosuppression(39). In allo-SCT recipients, presence of HHV-6 DNA was significantly associated with delayed platelet and neutrophil engraftment(8, 22). In our cohort of ASCT patients, we observed a delay in platelets and ANC reconstitution with consequences on durations of hospitalisations and need of late transfusions in patients with HHV-6 infections, potentially increasing the costs. One tricky point is that this 323 delayed hematopoietic reconstitution occurred before HHV-6 reactivation. However, it is 324 difficult to precisely date the onset time of HHV-6 infection in clinical practice: as our 325 definition of HHV-6 infection was very stringent and took 7 days, HHV-6 could have 326 clinical consequences even at infra-biological thresholds as seen with CMV(40), or at the 327 moment of the virus reactivation during the week apart between the 2 measurements. 
This is one of the explanations of the occurrence of delayed neutropenia recovery prior to the median of onset time of HHV-6 infection: neutropenia recovery is delayed by 2 days (10 versus 8 days) during HHV-6 infection while the median of onset time of HHV-6

331 infection is 13 days.

Furthermore, infected HHV-6 patients of our series exhibited more frequent and more severe non-infectious complications such as oral mucositis than those without HHV-6 infection. Although this data could be partly biased because HHV-6 infection was more frequent in case of BEAM conditioning regimen, and because it is difficult to precisely date the onset time of a complication, there is a continuum between the beginning and the paroxysm of the complication especially for the mucositis. Actually, this VIRAUT06 study was not designed to follow each complication in time and to use each variable as the primary endpoint. Our objective was mainly to make a descriptive study concerning HHV-6.

In conclusion, although systematic monitoring of HHV-6 DNAemia could not be recommended for all patients, HHV-6 infection must be evocated in case of delayed hematopoietic reconstitution or severe acute combined toxicities, notably after lymphoma's regimen. This study marks a step forward, but larger studies with patients receiving the same conditioning regimen prior to stem cell reinfusion would be warranted.

\section{ACKNOWLEDGMENTS SECTION}

Conflict of interest statement: There are no conflicts of interest to report.

\section{Authorship statement:}

Marie Balsat and Jérôme Cornillon conceived the study, provided clinical care, recorded and collected clinical data, analysed data, and wrote the manuscript. Sylvie Pillet performed biological analyses, recorded and collected biological data and wrote the manuscript. Mathieu Oriol and Véronique Bousser performed statistical analyses and commented on the manuscript. 
358 Emmanuelle Tavernier, Victoria Cacheux, Cécile Moluçon-Chabrot and Karine Augeul-

359 Meunier provided clinical care, recorded clinical data and commented on the

360 manuscript.

361 Vanessa Escuret, Audrey Mirand and Christel Regagnon performed biological analyses.

362 Fabien Tinquaut performed statistical analyses.

363 Gilles Salles and Bruno Pozzetto wrote and revised the manuscript.

364 Jacques-Olivier Bay and Denis Guyotat commented on the manuscript.

366 Funding

367 This research has received funding support from the Institut de Cancérologie

368 Lucien Neuwirth and the Ligue contre le cancer.

Acknowledgments

372 The authors are grateful to Prof Henri Agut for helpful discussions. 
1. Hill JA, Sedlak RH, Jerome KR. Past, present, and future perspectives on the diagnosis of Roseolovirus infections. Curr Opin Virol. 2014;9:84-90.

2. Hill JA, Zerr DM. Roseoloviruses in transplant recipients: clinical consequences and prospects for treatment and prevention trials. Curr Opin Virol. 2014;9:53-60.

3. Agut H, Bonnafous P, Gautheret-Dejean A. Human Herpesviruses 6A, 6B, and 7. Microbiol Spectr. 2016;4(3).

4. Agut H, Bonnafous P, Gautheret-Dejean A. Laboratory and clinical aspects of human herpesvirus 6 infections. Clin Microbiol Rev. 2015;28(2):313-35.

5. Isomura H, Yoshida M, Namba H, Yamada M. Interaction of human herpesvirus 6 with human CD34 positive cells. J Med Virol. 2003;70(3):444-50.

6. Pellett PE, Ablashi DV, Ambros PF, Agut H, Caserta MT, Descamps V, et al. Chromosomally integrated human herpesvirus 6: questions and answers. Rev Med Virol. 2012;22(3):144-55.

7. Caserta MT, McDermott MP, Dewhurst S, Schnabel K, Carnahan JA, Gilbert L, et al. Human herpesvirus 6 (HHV6) DNA persistence and reactivation in healthy children. J Pediatr. 2004;145(4):478-84.

8. de Pagter PJ, Schuurman R, Meijer E, van Baarle D, Sanders EA, Boelens JJ. Human herpesvirus type 6 reactivation after haematopoietic stem cell transplantation. J Clin Virol. 2008;43(4):361-6.

9. Imbert-Marcille BM, Tang XW, Lepelletier D, Besse B, Moreau P, Billaudel S, et al. Human herpesvirus 6 infection after autologous or allogeneic stem cell transplantation: a single-center prospective longitudinal study of 92 patients. Clin Infect Dis. 2000;31(4):881-6.

10. Fernandez-Ruiz M, Kumar D, Husain S, Lilly L, Renner E, Mazzulli T, et al. Utility of a monitoring strategy for human herpesviruses 6 and 7 viremia after liver transplantation: a randomized clinical trial. Transplantation. 2015;99(1):106-13.

11. Knox KK, Carrigan DR. Disseminated active HHV-6 infections in patients with AIDS. Lancet. 1994;343(8897):577-8.

12. Agut H. Deciphering the clinical impact of acute human herpesvirus 6 (HHV-6) infections. J Clin Virol. 2011;52(3):164-71.

13. Ogata M, Fukuda T, Teshima T. Human herpesvirus- 6 encephalitis after allogeneic hematopoietic cell transplantation: what we do and do not know. Bone Marrow Transplant. 2015;50(8):1030-6.

14. Hill JA, Myerson D, Sedlak RH, Jerome KR, Zerr DM. Hepatitis due to human herpesvirus 6B after hematopoietic cell transplantation and a review of the literature. Transpl Infect Dis. 2014;16(3):477-83.

15. Gotoh M, Yoshizawa S, Katagiri S, Suguro T, Asano M, Kitahara T, et al. Human herpesvirus 6 reactivation on the 30th day after allogeneic hematopoietic stem cell transplantation can predict grade 2-4 acute graft-versus-host disease. Transpl Infect Dis. 2014;16(3):440-9.

16. Phan TL, Carlin K, Ljungman P, Politikos I, Boussiotis V, Boeckh M, et al. Human Herpesvirus-6B Reactivation Is a Risk Factor for Grades II to IV Acute Graft-versus-Host Disease after Hematopoietic Stem Cell Transplantation: A Systematic Review and MetaAnalysis. Biol Blood Marrow Transplant. 2018;24(11):2324-36.

17. Zerr DM, Boeckh M, Delaney C, Martin PJ, Xie H, Adler AL, et al. HHV-6 reactivation and associated sequelae after hematopoietic cell transplantation. Biol Blood Marrow Transplant. 2012;18(11):1700-8. 
18. Dulery R, Salleron J, Dewilde A, Rossignol J, Boyle EM, Gay J, et al. Early human herpesvirus type 6 reactivation after allogeneic stem cell transplantation: a large-scale clinical study. Biol Blood Marrow Transplant. 2012;18(7):1080-9.

19. Shimazu Y, Kondo T, Ishikawa T, Yamashita K, Takaori-Kondo A. Human herpesvirus- 6 encephalitis during hematopoietic stem cell transplantation leads to poor prognosis. Transpl Infect Dis. 2013;15(2):195-201.

20. Attal M, Harousseau JL, Stoppa AM, Sotto JJ, Fuzibet JG, Rossi JF, et al. A prospective, randomized trial of autologous bone marrow transplantation and chemotherapy in multiple myeloma. Intergroupe Francais du Myelome. N Engl J Med. 1996;335(2):91-7.

21. Peinemann F, Enk H, Smith LA. Autologous hematopoietic stem cell transplantation following high-dose chemotherapy for nonrhabdomyosarcoma soft tissue sarcomas. Cochrane Database Syst Rev. 2017;4:CD008216.

22. Quintela A, Escuret V, Roux S, Bonnafous P, Gilis L, Barraco F, et al. HHV-6 infection after allogeneic hematopoietic stem cell transplantation: From chromosomal integration to viral co-infections and T-cell reconstitution patterns. J Infect. 2016;72(2):214-22.

23. Colombier MA, Amorim S, Salmona M, Thieblemont C, Legoff J, Lafaurie M. HHV-6 reactivation as a cause of fever in autologous hematopoietic stem cell transplant recipients. J Infect. 2017;75(2):155-9.

24. Schlaweck S, Bragelmann J, Brossart P, Mayer K. Exanthem subitum (human herpesvirus- 6 reactivation) after autologous stem cell transplantation. Transpl Infect Dis. 2016;18(2):255-6.

25. Chapenko S, Trociukas I, Donina S, Chistyakov M, Sultanova A, Gravelsina S, et al. Relationship between beta-herpesviruses reactivation and development of complications after autologous peripheral blood stem cell transplantation. J Med Virol. 2012;84(12):1953-60.

26. Styczynski J, Czyzewski K, Wysocki M, Gryniewicz-Kwiatkowska O, KolodziejczykGietka A, Salamonowicz M, et al. Increased risk of infections and infection-related mortality in children undergoing haematopoietic stem cell transplantation compared to conventional anticancer therapy: a multicentre nationwide study. Clin Microbiol Infect. 2016;22(2):179 e1- e10.

27. Fule Robles JD, Cheuk DK, Ha SY, Chiang AK, Chan GC. Human herpesvirus types 6 and 7 infection in pediatric hematopoietic stem cell transplant recipients. Ann Transplant. 2014;19:269-76.

28. Dueck AC, Mendoza TR, Mitchell SA, Reeve BB, Castro KM, Rogak LJ, et al. Validity and Reliability of the US National Cancer Institute's Patient-Reported Outcomes Version of the Common Terminology Criteria for Adverse Events (PRO-CTCAE). JAMA Oncol. 2015;1(8):1051-9.

29. Deback C, Agbalika F, Scieux C, Marcelin AG, Gautheret-Dejean A, Cherot J, et al. Detection of human herpesviruses HHV-6, HHV-7 and HHV-8 in whole blood by realtime PCR using the new CMV, HHV-6, 7, 8 R-gene kit. J Virol Methods. 2008;149(2):28591.

30. Ogata M, Kikuchi H, Satou T, Kawano R, Ikewaki J, Kohno K, et al. Human herpesvirus 6 DNA in plasma after allogeneic stem cell transplantation: incidence and clinical significance. J Infect Dis. 2006;193(1):68-79.

31. Inazawa N, Hori T, Nojima $M$, Saito $M$, Igarashi $K$, Yamamoto $M$, et al. Virus reactivations after autologous hematopoietic stem cell transplantation detected by multiplex PCR assay. J Med Virol. 2017;89(2):358-62. 
32. Jeulin H, Agrinier N, Guery M, Salmon A, Clement L, Bordigoni P, et al. Human herpesvirus 6 infection after allogeneic stem cell transplantation: incidence, outcome, and factors associated with HHV-6 reactivation. Transplantation. 2013;95(10):1292-8. 33. Pillet S, Roblin X, Cornillon J, Mariat C, Pozzetto B. Quantification of cytomegalovirus viral load. Expert Rev Anti Infect Ther. 2014;12(2):193-210. 34. Roux J, Battistella M, Fornecker L, Legoff J, Deau B, Houhou N, et al. Human Herpesvirus-6 cytopathic inclusions: an exceptional and recognizable finding on skin biopsy during HHV6 reactivation after autologous stem-cell transplantation. Am J 479 Dermatopathol. 2012;34(6):e73-6.

480 35. Hill JA, Ikoma M, Zerr DM, Basom RS, Peddu V, Huang ML, et al. RNA Sequencing 481 of the In Vivo Human Herpesvirus 6B Transcriptome To Identify Targets for Clinical 482 Assays Distinguishing between Latent and Active Infections. J Virol. 2019;93(3). 36. Ljungman P, Wang FZ, Clark DA, Emery VC, Remberger M, Ringden O, et al. High levels of human herpesvirus 6 DNA in peripheral blood leucocytes are correlated to platelet engraftment and disease in allogeneic stem cell transplant patients. $\mathrm{Br} \mathrm{J}$ Haematol. 2000;111(3):774-81.

487 37. Gafter-Gvili A, Polliack A. Bendamustine associated immune suppression and 488 infections during therapy of hematological malignancies. Leuk Lymphoma. 489 2016;57(3):512-9.

$490 \quad 38 . \quad$ Horowitz N, Oren I, Lavi N, Zuckerman T, Benyamini N, Kra-Oz Z, et al. New rising infection: human herpesvirus 6 is frequent in myeloma patients undergoing autologous stem cell transplantation after induction therapy with bortezomib. Bone Marrow Res. 2012;2012:409765.

494 39. Andre-Garnier E, Milpied N, Boutolleau D, Saiagh S, Billaudel S, Imbert-Marcille 495 BM. Reactivation of human herpesvirus 6 during ex vivo expansion of circulating CD34+ 496 haematopoietic stem cells. J Gen Virol. 2004;85(Pt 11):3333-6.

497 40. Razonable RR, Hayden RT. Clinical utility of viral load in management of 498 cytomegalovirus infection after solid organ transplantation. Clin Microbiol Rev. 499 2013;26(4):703-27. 


\section{FIGURE LEGEND}

Figure 1: HHV-6 infection cumulative incidence. Dotted lines represent standard deviations. HHV-6 infection occurred with a cumulative incidence of $19 \%$ at 40 days after transplantation

\section{Figure 2:}

A ; Kinetics of platelet recovery (platelets > $20 \times 10^{9} / \mathrm{L}$ ) according to HHV-6 infection. HHV-6 +: recipients exhibiting HHV-6 infection; HHV-6 -: recipients without HHV-6 infection.

B ; Kinetics of neutropenia recovery (ANC > $0.5 \times 10^{9} / \mathrm{L}$ ) according to HHV-6 infection. HHV-6 +: recipients exhibiting HHV-6 infection; HHV-6 -: recipients without HHV-6 infection. 
Figure 1:

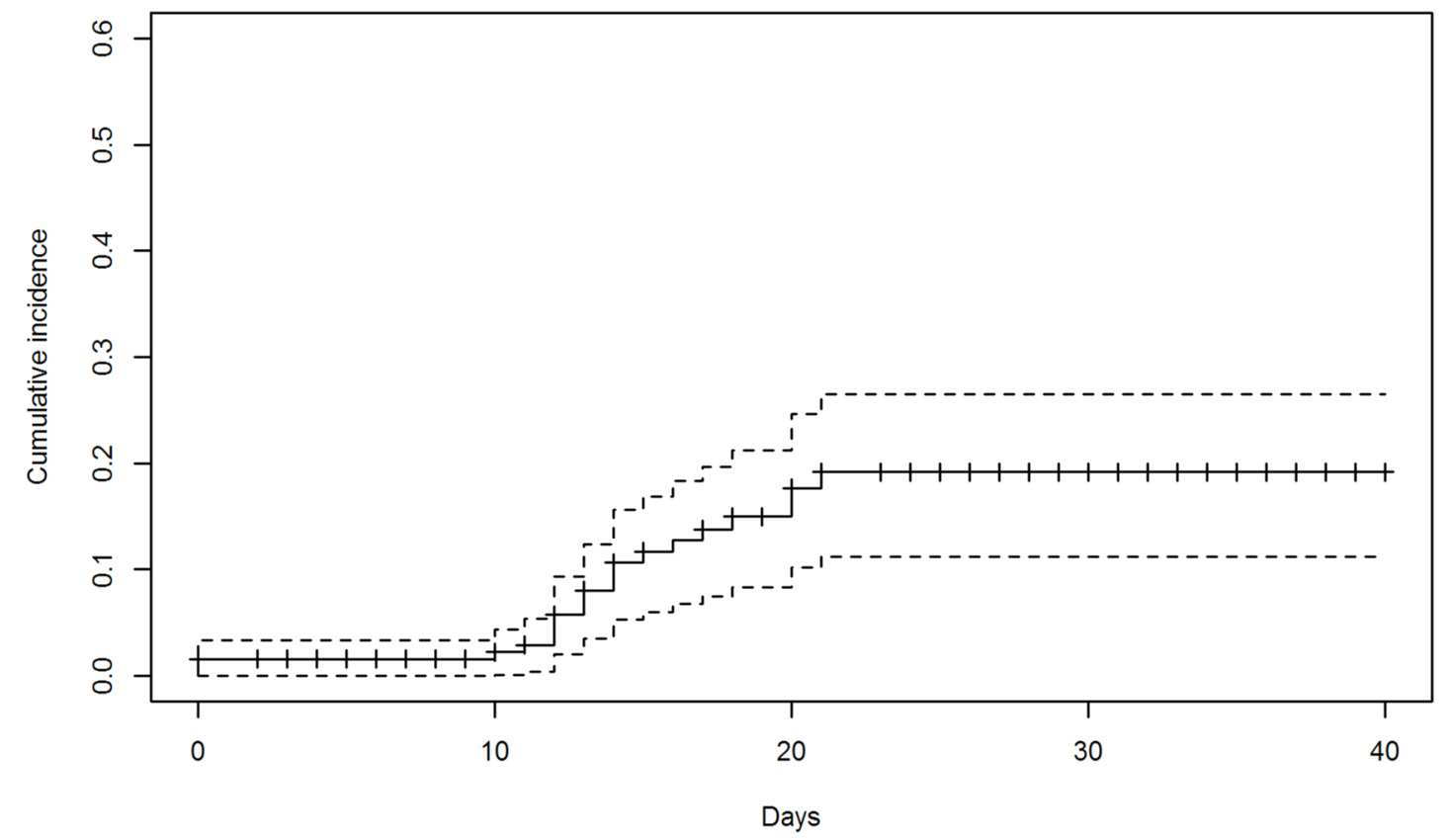


Figure 2:

A

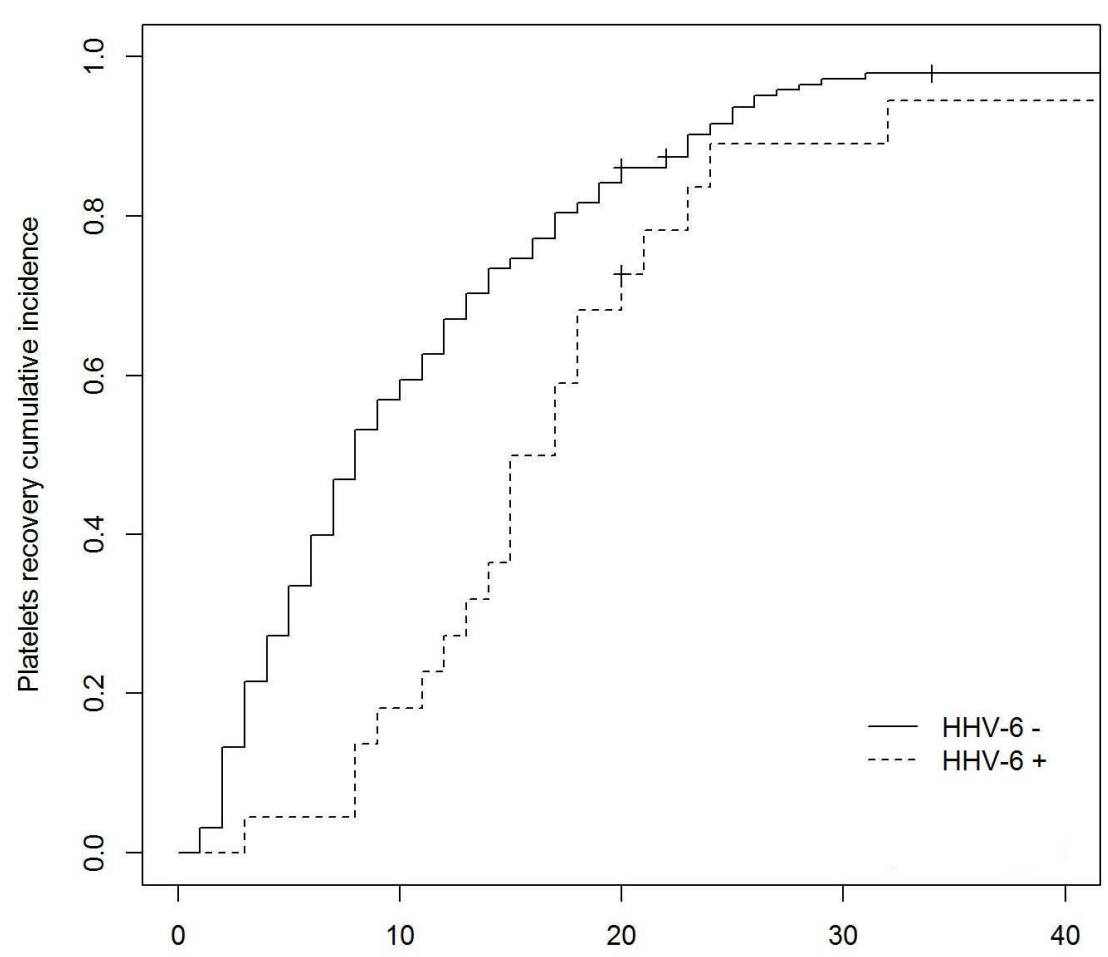

B

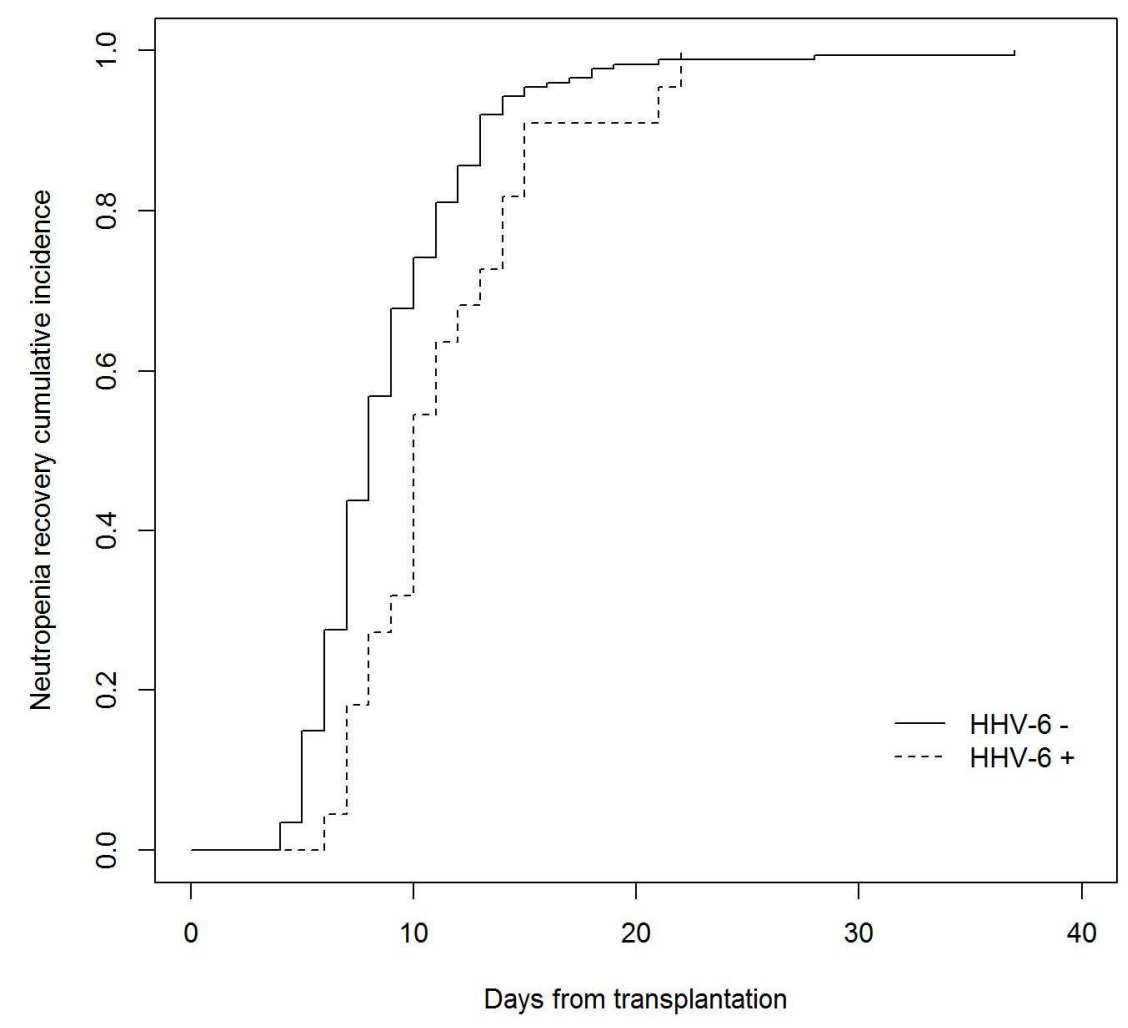


TABLES

Table 1: Baseline characteristics of the patients according to HHV-6 infected status

\begin{tabular}{|c|c|c|c|c|}
\hline Patients' Baseline Characteristics, & $\begin{array}{c}\text { Non-infected patients } \\
(\mathrm{n}=174) \\
\mathrm{n}(\%)\end{array}$ & $\begin{array}{c}\text { HHV-6-infected patients } \\
(\mathrm{n}=22) \\
\mathrm{n}(\%)\end{array}$ & $\begin{array}{c}\text { TOTAL }(\mathrm{n}=196) \\
\mathrm{n}(\%)\end{array}$ & P-value \\
\hline Sex (male/female) & $113 / 61$ & $14 / 8$ & $127 / 69$ & 0.99 \\
\hline Median age (range) & $59.5(53.6-64.8)$ & $58.2(48.6-61.8)$ & $59.4(52.5-64.8)$ & 0.29 \\
\hline \multicolumn{5}{|l|}{ Underlying diseases } \\
\hline Non Hodgkin lymphoma & $72(41.4 \%)$ & $17(77.3 \%)$ & $89(45.4 \%)$ & 0.001 \\
\hline Multiple myeloma & $84(48.3 \%)$ & $2(9.1 \%)$ & $86(43.9 \%)$ & \\
\hline Hodgkin lymphoma & $16(9.2 \%)$ & $3(13.6 \%)$ & $19(9.7 \%)$ & \\
\hline Acute leukemia & $1(0.6 \%)$ & 0 & $1(0.5 \%)$ & \\
\hline NA & $1(0.6 \%)$ & 0 & $1(0.5 \%)$ & \\
\hline \multicolumn{5}{|l|}{ Non Hodgkin Lymphoma } \\
\hline Diffuse large B cell lymphoma & $32(44.4 \%)$ & $8(47.1 \%)$ & $40(44.9 \%)$ & 0.72 \\
\hline Mantle cell lymphoma & $14(19.4 \%)$ & $4(23.5 \%)$ & $18(20.2 \%)$ & \\
\hline Follicular lymphomas & $11(15.3 \%)$ & $4(23.5 \%)$ & $15(16.9 \%)$ & \\
\hline T cell lymphomas & $8(11.1 \%)$ & $1(5.9 \%)$ & $9(10.1 \%)$ & \\
\hline Others & $7(9.7 \%)$ & 0 & $7(7.9 \%)$ & \\
\hline \multicolumn{5}{|l|}{ Disease status at transplantation } \\
\hline CR and VGPR & $111(63.8 \%)$ & $14(63.6 \%)$ & $125(63.8 \%)$ & 0.99 \\
\hline $\mathrm{PR} / \mathrm{SD}$ & $62(35.6 \%)$ & $8(36.4 \%)$ & $70(35.7 \%)$ & \\
\hline $\mathrm{RD}$ & $1(0.6 \%)$ & 0 & $1(0.5 \%)$ & \\
\hline \multicolumn{5}{|l|}{ Conditioning regimen } \\
\hline BEAM & $76(43.7 \%)$ & $17(77.3 \%)$ & $93(47.4 \%)$ & $<0.001$ \\
\hline Melphalan & 85 (48.9\%) & $2(9.1 \%)$ & $87(44.4 \%)$ & \\
\hline Others & $13(7.5 \%)$ & $3(13.6 \%)$ & $16(8.2 \%)$ & \\
\hline
\end{tabular}




\section{Number of treatment prior to}

transplantation

\begin{tabular}{rcccc}
1 & $102(58.6 \%)$ & $12(54.5 \%)$ & $114(58.2 \%)$ & 0.82 \\
$2-4$ & $72(41.4 \%)$ & $10(45.5 \%)$ & $82(41.8 \%)$ & \\
& & & & \\
$C M V-$ & $88(53.3 \%)$ & $14(70 \%)$ & $102(55.1 \%)$ & 0.23 \\
CMV + & $77(46.7 \%)$ & $6(30 \%)$ & $83(44.9 \%)$ & \\
NA & $9(5.2 \%)$ & $2(9.1 \%)$ & $11(5.6 \%)$ & \\
\hline
\end{tabular}

$\mathrm{NA}=$ Not available, $\mathrm{CR}=$ Complete remission, $\mathrm{VGPR}=$ very good partial response, $\mathrm{PR}=$ partial response, $\mathrm{SD}=$ stable disease, $\mathrm{RD}=$ refractory disease .

$\mathrm{BEAM}=$ Carmustine-Etoposide-Cytarabine-Melphalan conditioning regimen; CMV - =Negative serostatus for cytomegalovirus (CMV); CMV + = Positive serostatus for CMV. 
Table 2: Univariate analysis of HHV-6 reactivation with the survival analysis method (HHV-6 taken as a time-dependent variable).

\begin{tabular}{|c|c|c|c|c|}
\hline & & HR.95.Cl. & P.Wald.s.test. & P-value \\
\hline Sex & Male vs Female & $1.18(0.86,1.62)$ & 0.306 & 0.311 \\
\hline \multirow[t]{4}{*}{ Age } & ref. $=(18,52]$ & & & 0.847 \\
\hline & $(52,60]$ & $0.98(0.64,1.49)$ & 0.919 & \\
\hline & $(60,65]$ & $0.97(0.62,1.53)$ & 0.912 & \\
\hline & $(65,71]$ & $1.14(0.73,1.77)$ & 0.574 & \\
\hline Disease status at transplantation & $P R+S D+R D$ vs $C R$ and VGPR & $0.94(0.68,1.29)$ & 0.686 & 0.715 \\
\hline \multirow[t]{3}{*}{ Conditioning regimen } & ref. $=B E A M$ & & & 0.055 \\
\hline & Other & $1.6(0.88,2.89)$ & 0.123 & \\
\hline & melphalan & $1.42(1.03,1.94)$ & 0.03 & \\
\hline \multirow[t]{4}{*}{$\begin{array}{l}\text { Number of treatment prior to } \\
\text { transplantation }\end{array}$} & ref. $=1$ & & & 0.41 \\
\hline & 2 & $1.04(0.75,1.45)$ & 0.819 & \\
\hline & 3 & $1.05(0.56,1.98)$ & 0.867 & \\
\hline & 4 & $0.51(0.22,1.18)$ & 0.116 & \\
\hline
\end{tabular}

$C R=$ Complete remission, $V G P R=$ very good partial response, $P R=$ partial response,$S D=$ stable disease, $R D=$ refractory disease. $\mathrm{BEAM}=$ Carmustine-Etoposide-Cytarabine-Melphalan conditioning regimen 
Table 3: Comparison of non-infectious with infectious complications according to HHV-6 infected status

\begin{tabular}{|c|c|c|c|}
\hline$N=196$ & $\begin{array}{c}\text { Non-infected patients } \\
\mathrm{n}(\%)\end{array}$ & $\begin{array}{c}\text { HHV-6-infected } \\
\text { patients } \\
\text { n (\%) }\end{array}$ & $\begin{array}{l}\text { Total } \\
\text { n (\%) }\end{array}$ \\
\hline \multicolumn{4}{|l|}{ Non infectious complications } \\
\hline Oral mucositis & $141(81 \%)$ & $17(77.3 \%)$ & $158(80.8 \%)$ \\
\hline Grade 1 & $33(23.4 \%)$ & $2(11.8 \%)$ & $35(22.2 \%)$ \\
\hline Grade 2 & $38(27 \%)$ & $1(5.9 \%)$ & $39(24.7 \%)$ \\
\hline Grade 3 & $52(36.9 \%)$ & $12(70.6 \%)$ & $64(40.5 \%)$ \\
\hline Grade 4 & $15(10.6 \%)$ & $2(11.8 \%)$ & $17(10.8 \%)$ \\
\hline NA & $3(2.1 \%)$ & $0(0 \%)$ & $3(1.9 \%)$ \\
\hline Diarrhea & $127(73 \%)$ & $9(40.9 \%)$ & $136(69.4 \%)$ \\
\hline Liver enzyme elevation & $111(63.8 \%)$ & $16(72.7 \%)$ & $127(64.8 \%)$ \\
\hline Skin rash & $58(33.3 \%)$ & $11(50 \%)$ & $69(35.2 \%)$ \\
\hline Acute kidney injury & $23(13.2 \%)$ & $4(18.2 \%)$ & $27(13.8 \%)$ \\
\hline \multicolumn{4}{|l|}{ Infectious complications } \\
\hline Febrile neutropenia & $109(62.6 \%)$ & $15(68.2 \%)$ & $124(63.3 \%)$ \\
\hline \multicolumn{4}{|l|}{ Clinically/microbiologically sites involved } \\
\hline Gut & $50(28.7 \%)$ & $5(22.7 \%)$ & 55 (28.1\%) \\
\hline Urinary tract & 49 (28.2\%) & 7 (31.8\%) & $56(28.6 \%)$ \\
\hline Septicaemia & $53(30.5 \%)$ & 8 (36.4\%) & 61 (31.1\%) \\
\hline Lung & $10(5.7 \%)$ & $1(4.5 \%)$ & $11(5.6 \%)$ \\
\hline
\end{tabular}

